\title{
Archaeological Assessments for the San Antonio 201 Wastewater Treatment Project: Survey of Five Pipeline Routes and Testing at Site 41BX333
}

Ralph Snavely

Margaret Greco

Anne A. Fox

Follow this and additional works at: https://scholarworks.sfasu.edu/ita

Part of the American Material Culture Commons, Archaeological Anthropology Commons, Environmental Studies Commons, Other American Studies Commons, Other Arts and Humanities Commons, Other History of Art, Architecture, and Archaeology Commons, and the United States History Commons

Tell us how this article helped you.

This Article is brought to you for free and open access by the Center for Regional Heritage Research at SFA ScholarWorks. It has been accepted for inclusion in Index of Texas Archaeology: Open Access Gray Literature from the Lone Star State by an authorized editor of SFA ScholarWorks. For more information, please contact cdsscholarworks@sfasu.edu. 


\section{Archaeological Assessments for the San Antonio 201 Wastewater Treatment Project: Survey of Five Pipeline Routes and Testing at Site 41BX333}

\section{Creative Commons License}

\section{(c) (1) \&}

This work is licensed under a Creative Commons Attribution-NonCommercial 4.0 International License 


\author{
ARCHAEOLOGICAL ASSESSMENTS FOR THE \\ SAN ANTONIO 201 WASTEWATER TREATMENT PROJECT: \\ SURVEYS OF FIVE PIPELINE ROUTES \\ AND TESTING AT SITE 41 BX 333
}

RaTph Snavely, Margaret Greco, and Anne A. Fox

Center for Archaeological Research

The University of Texas at San Antonio

Archaeological Survey Report, No. 131 



\section{ARCHAEOLOGICAL ASSESSMENTS FOR THE \\ SAN ANTONIO 201 WASTEWATER TREATMENT PROJECT: \\ SURVEYS OF FIVE PIPELINE ROUTES \\ AND TESTING AT SITE 41 BX 333}

Ralph Snavely, Margaret Greco, and Anne A. Fox

Investigations conducted under

Texas Antiquities Committee Permit No. 378

Center for Archaeological Research The University of Texas at San Antonio ${ }^{\circledR}$

Archaeological Survey Report, No. 131 
The following information is provided in accordance with General Rules of Practice and Procedure Chapter 41.11 (Investigation Reports), Texas Antiquities Committee:

1. Type of investigation: Pipeline route survey and limited testing at prehistoric site $41 \mathrm{BX} 333$;

2. Project name: San Antonio 201 Wastewater Facilities Improvements Project;

3. County: Bexar County, Texas;

4. Principal Investigator: Thomas R. Hester; Co-Principal Investigators: Jack D. Eaton and Anne A. Fox;

5. Name and location of sponsoring agency: City of San Antonio, through A Joint Venture of Consulting Engineers;

6. Texas Antiquities Committee Permit No. 378;

7. Published by the Center for Archaeological Research, The University of Texas at San Antonio, San Antonio, Texas 78285, 1984.

A list of publications offered by the Center for Archaeological Research can be obtained by sending $\$ 1.00$ to the Center for Archaeological Research, The University of Texas at San Antonio, San Antonio, Texas 78285. 


\section{ABSTRACT}

During August to October 30, 1983, the Center for Archaeological Research, The University of Texas at San Antonio, carried out archaeological assessments in south Bexar County for the San Antonio 201 Wastewater Facilities Improvements Project. These consisted of pedestrian surveys of five pipeline routes and subsurface testing at site $47 \mathrm{BX} 333$. No significant cultural resources were found within the pipeline easements or at $41 \mathrm{BX} 333$. However, four prehistoric sites and one probable historic site were recorded in the vicinity of the pipeline route, but they were well outside of the easement. None appear to meet the eligibility criteria for the National Register of Historic Places, and no further work is recommended at this time. 
TABLE OF CONTENTS

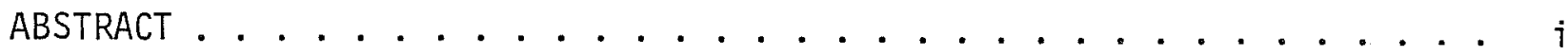

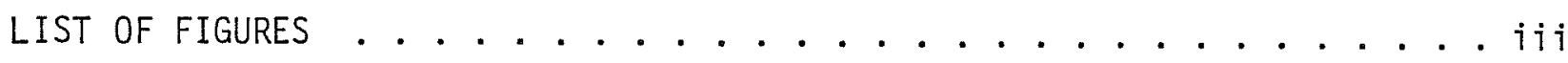

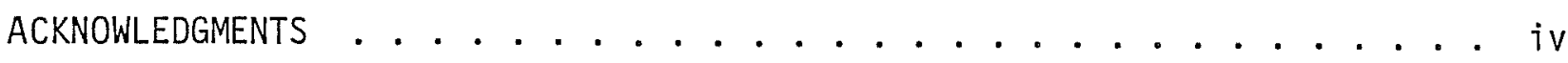

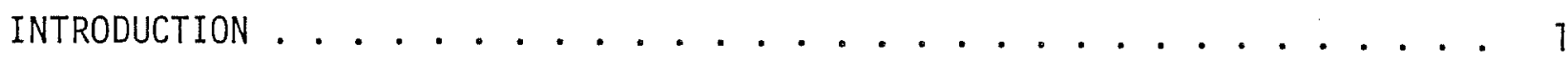

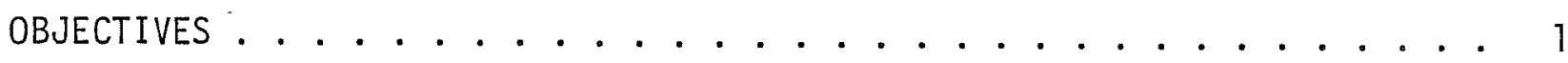

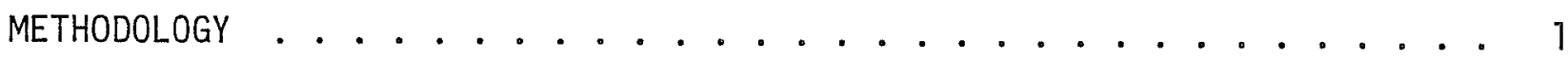
PREVIOUS ARCHAEOLOGICAL RESEARCH ................ 3

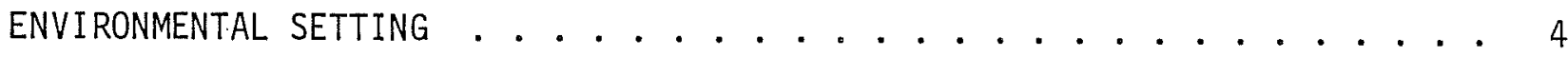

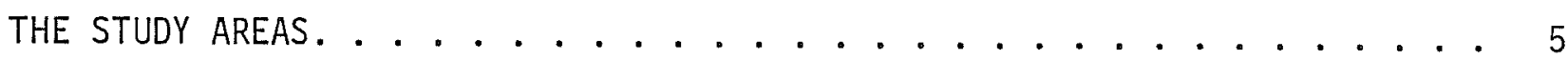
THE SURVEY AND TESTING ................... 6 Site 41 BX $595 \ldots \ldots 6$

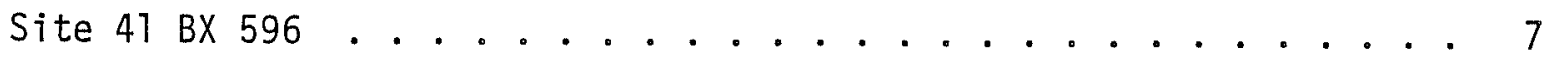
Site 41 BX $598 \ldots \ldots . . \ldots 9 . \ldots . . . \ldots 9$ Site 41 BX $599 \ldots \ldots . \ldots . \ldots . \ldots . \ldots 9$

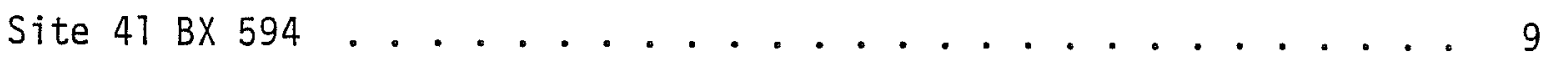

The Anthony Granieri Collection . . . . . . . . . . 13

Testing at $41 \mathrm{BX} 333 \ldots \ldots 13$ SUMMARY AND CONCLUSIONS ............................... 14

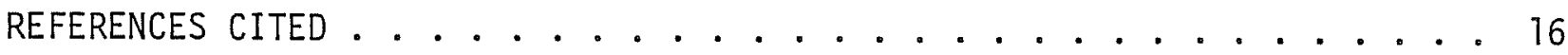




\section{LIST OF FIGURES}

1. Locations of Sewer Line Routes for Packages B, C, D, and J . . . . . 2

2. Portions of Package $B$ Sewer Line Route Indicating Locations of Sites 41 BX 595 and 41 BX $596 \ldots . . . . . . . . . .88$

3. Upper Portion of Package C Indicating Location of Site 41 BX 598 . . . 10

4. Lower Portion of Package C Indicating Location of Site 41 BX 599 . . . 11

5. Package J (SR-152) Sewer Line Route Indicating Location of Site 41 BX 594 ......................... 12

6. Location of $41 \mathrm{BX} 333$ at the Leon Creek Wastewater Treatment Plant Facility ................. 15 


\section{ACKNOWLEDGMENTS}

We are grateful to a number of people who greatly expedited the work of the survey. Mr. Salah Diab, of Joint Venture, was very helpful in providing essential assistance. Landowner Anthony Granieri kindly allowed us to see his personal artifact collection from the area. The preparation of this report was aided by Jack Eaton, Sharon Quirk, and Mary Lou E11is. 


\section{INTRODUCTION}

During August 29 to October 30, 1983, personne] from the Center for Archaeological Research (CAR), The University of Texas at San Antonio (UTSA), carried out surveys and testing as part of a continuation of archaeological assessments for the San Antonio 201 Wastewater Facilities Improvements Project. In this particular instance archaeological surveys of five sewer pipeline routes were conducted, as was limited testing at 47 BX 333 in south Bexar county for the City of San Antonio. The work was done under the terms and conditions of the existing 1976 Professional Services Contract between the City of San Antonio (through Joint Venture of Consulting Engineers) and the Center for Archaeological Research. The surveys reported herein were requested in the Memorandum of Understanding, dated August 25, 1983, issued by Joint Venture. The testing of 41 BX 333 was done under Texas Antiquities Committee Permit No. 378.

The archaeological field studies comply with the Texas Antiquities Code, the National Historic Preservation Act of 1966, the National Environmental Policy Act of 1969 (NEPA), and Executive Order 11593 as part of the planning process required for the construction of federally funded wastewater works under Section 201, Federal Water Pollution Control Act Amendments of 1972 (PL 92-500). The project in which the archaeological investigations are involved was funded in part by grants from the United States Environmental Protection Agency.

This report will be concerned with the surveys of routes of proposed alignment of Category No. 4, Packages B, C, and D, as well as surveys of Package J (SR152 and LR-108) pipeline routes. These survey routes were indicated on maps provided by Joint venture and are shown in Figure 1. In addition, the results of testing at archaeological site $41 \mathrm{BX} 333$, a previously recorded prehistoric site located at the Leon Creek Wastewater Treatment Plant, will also be presented.

The field work reported herein was carried out by Margaret Greco and Ralph Snavely, Technical Staff Assistants, under the supervision of Anne Fox, Research Associate. Overall project supervision was provided by Dr. Thomas R. Hester, Center Director, and Jack Eaton, Associate Director.

\section{OBJECTIVES}

The main objectives of the pipeline route surveys and testing at 41 BX 333 were: (1) to determine the presence or absence of archaeological resources within each area that might be affected by construction of sewer 1 ines; (2) record, identify, and appraise the relative significance of any cultural resource discovered; and (3) to make recommendations for further work in order to determine eligibility for nomination to the National Register of Historic Places for 41 BX 333 and any other sites found along the pipeline routes. In order to accomplish these objectives, we employed the methodology described in the following section.

\section{METHODOLOGY}

The pipeine surveys were divided into five different sections, to include Packages B (SR-159), C (LR-101), D (LR-101), and J (SR-152 and LR-108). The 


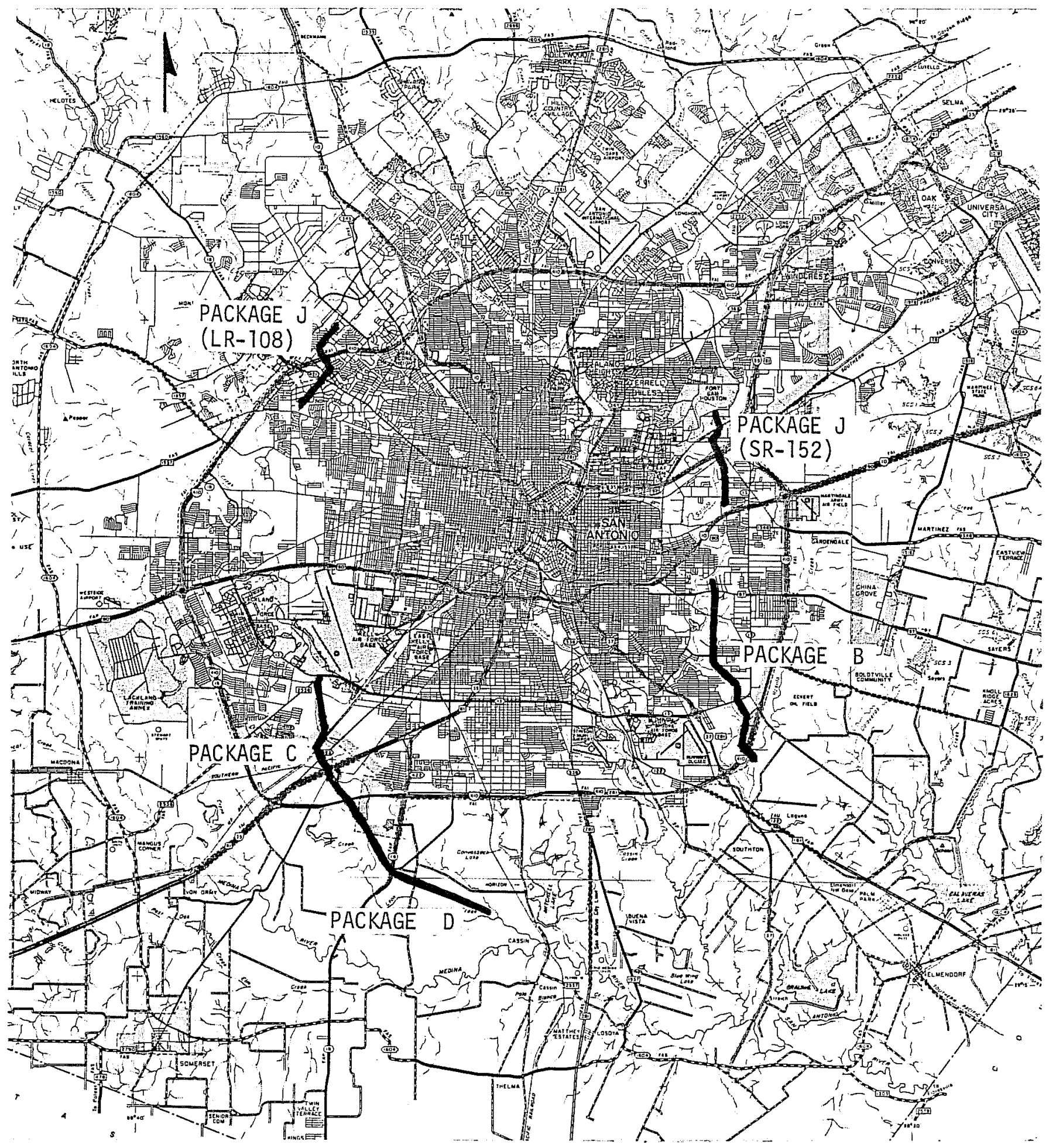

Figure 1. Locations of Sewer line Routes for Packages $B, C, D$, and $J$. The bo 1d lines indicate proposed sewer line routes. 
routes of the surveys were clearly defined from information obtained from USGS topographic and aerial maps provided by Joint Venture. In addition, sewer 1 ines previously placed within the existing city easements denoted the exact route of the proposed sewer lines, which would be placed parallel to and close by the existing lines.

The actual survey coverage for each route included approximately $25 \mathrm{~m}$ on either side of the proposed sewer line, which was beyond the easement, but with careful observations being made on the direct impact areas. As sites, features, and artifacts were observed, they were recorded on site survey forms, and photographs were taken. Al1 sites found were well outside of the pipeline easement.

No artifact collections were made. When concentrations of artifacts (mostly lithic debitage) were found, they were documented and left in place. In addition, several interviews with landowners were conducted; this resulted in the documentation of an artifact collection.

Sites that were located have been assigned permanent trinomial numbers reflecting the state (41), the county $(B X)$, and an individual, sequential number for each site assigned by the Texas Archeological Research Laboratory in Austin, Texas. Site locations have been plotted on United States Geological Survey topographic maps (7.5 minute series) at the CAR-UTSA. The site data are on file at the CAR, and duplicate forms have been furnished to the Texas Archeological Research Laboratory, Austin.

A previously recorded prehistoric site, $41 \mathrm{BX} 333$, was shovel tested to determine the spatial extent of the site. To accomplish this goal a series of carefully placed $50-\mathrm{cm}^{2}$ shovel tests, ranging in depth from $30 \mathrm{~cm}$ to $40 \mathrm{~cm}$ below the ground surface, was excavated. The soil from these tests was passed through a $1 / 4-$ inch wire mesh screen for cultural materials recovery.

\section{PREVIOUS ARCHAEOLOGICAL RESEARCH}

More than 500 archaeological sites have been recorded in Bexar County, making it one of the most archaeologically studied counties in Texas. Most of these sites have only been investigated on the preliminary survey level, but a few authors have studied the archaeology of the area on a county-wide scale. Woolford (1935) produced a general analys is of sites in this area based on his personal observations. Fawcett (1972) published a more complete archaeological report reviewing all prior work in Bexar County. A number of studies conducted by the CAR-UTSA have contributed a vast amount of archaeological data. These investigations include Hester et al. (1974), Smith and McDonald (1975), Fox (1977), McGraw and Valdez (1977, 1978), and Gerstle, Kel1y, and Assad (1978).

Sites of major archaeological significance in Bexar County include 41 BX 1 , the 01mos Dam site; 41 BX 17, the Granburg site; 41 BX 22, the Rodgers site; 41 BX 228, the Walker Ranch site; and 41 BX 229, the St. Mary's Hall site. These sites represent occupations of a temporal variety from the Paleo-Indian through the historic Indian periods of south-central Texas. A background on 
the archaeology of south-central Texas is provided in Hester (1980) and Black and McGraw (1984).

A review of previous archaeological research illustrates several types of prehistoric sites which may be found in Bexar County. A description taken from Fox $(1977: 1)$ as to the site types of this area and associated cultural remains is as follows:

Long-term or traditionally revisited occupation sites (campsites) are characterized by deep deposits containing stone tools, projectile points and the debris resulting from their manufacture and repair. Fragments of animal bones, snails and mussel shells will often be present, along with scattered limestone hearth stones. Temporary camping sites (related to short-term hunting or food gathering activities) are reflected by a thin scatter of chert flakes, hearth stones and tools in a limited area. 0ccasionally these temporary campsites occur in sheltered overhangs in the bluffs of northern Bexar County streams. Quarries and workshop areas occur near the outcrops of chert, usually in areas of exposed limestone. Such sites are numerous in the northern part of the county. These sites are characterized by numerous nodules of chert and debris resulting from the primary processes of tool manufacture.

\section{ENVIRONMENTAL SETTING}

This section presents a brief review of the present environmental conditions within the five pipeline survey areas. Vegetational patterns and pertinent soil observations are included in the description of the five survey areas. For additional information the reader is referred to Fawcett (1972), Scurlock and Hudson (1973), Hudson, Lynn, and Scurlock (1974), Gerstle, Kelly, and Assad (1978), and Taylor, Hailey, and Richmond (1966).

The climate of Bexar County is subtropical, with mild winters and hot summers. The dai7y maximum and minimum temperature averages are $79.2^{\circ} \mathrm{F}$ and $53.1^{\circ} \mathrm{F}$, respectively. Precipitation is usually evenly distributed throughout the year, averaging 27.84 inches per year (Taylor, Hailey, and Richmond 1966).

Bexar County lies in the transition zone between the southern limits of the Edwards Plateau and the northern rim of the South Texas Coastal Plain. The water drainage pattern in Bexar County is in a south to southeastward direction. The major streams of the county are Cibolo Creek, Leon Creek, Medina River, San Antonio River, and Salado Creek. The northern half of the county is characterized by prominent eroding limestone uplifts and a thin, calcareous soil. The southern half of the county is characterized by gently rolling hills and a deep sandy loam soil (Taylor, Hailey, and Richmond 1966).

A detailed study of the flora and fauna of the survey area is beyond the scope of this report. The study area falls within portions of three biotic provinces 
as discussed by Blair (1950): the Balconian, Texan, and Tamaulipan Biotic Provinces. Additional information on the flora and fauna may be obtained from Blair (1950), Davis (1974), and Gerstle, Kelly, and Assad (1978).

Within the study area there are three distinct soil associations: Houston BlackHouston (deep clayey soils over calcareous clay); Venus-Frio-Trinity (deep, calcareous soils on bottomlands and lower terraces); and Lewisville-Houston Black (terrace associated, deep, calcareous soils in old alluvium). These three soil associations are often mixed, a complication resulting from erosion and redeposition of alluviums (for more detail refer to Taylor, Hailey, and Richmond 1966).

\section{THE STUDY AREAS}

The areas surveyed were located parallel with and immediately adjacent to pipelines which were installed by the City of San Antonio 10 to 15 years ago. As noted above, these pipeline routes were divided into five sections designated Packages $B, C, D$, and $J$ with two sections (Fig. 1).

Package B (SR-159) extends along Salado Creek in southeast San Antonio beginning three blocks north of Rigsby Avenue and terminating just south of Loop 410 . The distance covered in this section was $8100 \mathrm{~m}$. The topography of the survey area was heavily altered by land clearing activities, plowed fields, and modern building construction. The predominant soil is a brown to tan sandy loam of the Venus-Frio-Trinity soil association (Taylor, Hailey, and Richmond 1966). This type of soil occurs throughout the bottomlands and along the initial terraces of Salado creek. The vegetation of this area includes mesquite and oak trees intermittentiy mixed. Much of the ground surface of the Package $B$ area has been altered in modern times by floods, erosion control efforts, intensive agriculture, and road and other construction.

Package C (LR-101) of the proposed sewer line extends along Leon Creek in southwest San Antonio, beginning at Kel1y Air Force Base and terminating at Highway 16. The distance covered in this section was $1000 \mathrm{~m}$ and consisted primarily of plowed fields. Houston Black-Houston, Lewisville-Houston Black, and VenusFrio-Trinity soil associations (Taylor, Hailey, and Richmond 1966) were noted in the Package $C$ area. Two of these soil associations--Lewisville-Houston Black and Venus-Frio-Trinity--occur equally in approximately $80 \%$ of the survey route. The Houston $B$ lack-Houston soil association occurs on the relatively level to gently rolling land on the east side of Leon Creek, and the LewisvilleHouston Black soil association is predominant within the flood zone. The vegetation along Leon Creek is typical of a riverine environment in south-central Texas. The ground cover consisted of thick grass and weeds often obscuring the ground surface visibility.

Package D (LR-101) of the proposed sewer line also extends along Leon Creek in southwest San Antonio, as it is actually an extension of Package $C$. The northern end of this survey area begins at Highway 16 and continues southeast and terminates at the Leon Creek Wastewater Treatment Plant. Package D survey parallels Leon Creek on its east side and extends a total distance of $2400 \mathrm{~m}$. 
Plowed and standing fields characterize this section of the survey. The soits have a distinctive Lewisville-Houston Black association. The deep calcareous clayey soils in old alluvium create favorable farmland conditions. The vegetation in direct association with Leon Creek predominantiy consisted of tall grass and mesquite trees. Over $90 \%$ of the land upland from the flood and erosional zone is under cultivation.

Package J (LR-108) of the proposed sewer line extends along Leon Creek. This survey area begins where Babcock Road crosses Leon Creek and extends ca. $4500 \mathrm{~m}$ along the creek to the intersection of Bandera and Callaghan Roads. The route is within the flood zone along the east and west sides of Leon Creek. This survey route was characterized by housing developments and hindered by concrete embankments as well as other land modifications. The areas that were least disturbed indicated a Lewisville-Houston Black soil association. The vegetation had been altered by land clearing activities, and sunflowers and tall weeds obscured the ground surface in the areas least disturbed.

Package J (SR-152) extends from the point where Salado Creek crosses W. W. White Road and continues ca. $3700 \mathrm{~m}$ along the west bank and ends at the crossing of Gembler Road and Salado Creek. This route is characterized by very dense vegetation which impeded survey efforts. Cypress, mesquite, and oak trees, sunflowers, tall grasses, and weeds represent the predominant types of vegetation. A Venus-Frio-Trinity soil association was noted within the flood zone and upper terraces on both sides of Salado Creek.

Site 41 BX 333 is located on the Leon Creek Wastewater Treatment Plant facility grounds, on the west side of the confluence of Comanche and Leon Creeks south of San Antonio. The site was recorded as being circular and ca. $80 \mathrm{~m}$ in size during a previous survey by a CAR-UTSA survey team and was recommended for testing to determine its significance and eligibility for nomination to the National Register of Historic Places (Fox, McGraw, and Valdez 1978).

\section{THE SURVEY AND TESTING}

The surveys of the five routes of the proposed sewer lines resulted in the discovery of four previously unrecorded prehistoric archaeological sites as well as one probable historic site. These are designated $47 \mathrm{BX} 595,41 \mathrm{BX} 596$, $41 \mathrm{BX} 598,41 \mathrm{BX} 599$, and 41 BX 594. Although al1 of the sites were found wel1 outside of the pipeline easement, they will be briefly described since they are in the vicinity of the impact zones. Also, brief note will be made regarding a landowner's private artifact collection from an area near the Package $B$ route. In addition, the results of the testing at $41 \mathrm{BX} 333$ will be presented in this section.

Site 41 BX 595 (Package B)

Site 41 BX 595, a prehistoric site, is located on the east side of Salado Creek, $400 \mathrm{~m}$ southeast of the intersection of Texoma and Winesap Streets. The site is situated on a gently sloping hillside, with the upper end on an erosional tributary of Salado Creek which is to the immediate east. This site appears to be 
oval in shape and covers an area of about $40 \times 60 \mathrm{~m}$. The easternmost part of the site wraps around the upper end of the erosional tributary (Fig. 2).

The site is characterized by a thin lithic scatter, but with a small, relatively concentrated area of thinning flakes. Other artifacts that were observed on the surface include a burned biface fragment, exhausted cores, and flakes. Most of the chert debris showed signs of thermal alteration.

The vegetation of this area consists of thick grasses and sunflowers with a few mesquite and huisache trees bordering the eroded area. The entire site area has been cleared with earth-moving machinery. The land clearing is a result of recent housing developments to the north and east of the site. In some areas the topsoil is completely removed. The soil remaining is a brown to tan sandy loam. A Venus-Frio-Trinity soil association occurs in this area.

The proposed sewer line will pass approximately $35 \mathrm{~m}$ to the southwest of the westernmost limits of the site and should not affect the resources. Because of the shallow character of the site, recent surface modification due to bulldozers, and limited surface material, no further archaeological work in conjunction with 41 BX 595 is recommended.

\section{Site 47 BX 596 (Package B)}

Site 41 BX 596, a prehistoric site, is located on the northeast side of Salado Creek, $70 \mathrm{~m}$ west of the high voltage line which runs north and south through the area. The site is situated partially on the north face of a sloping, terraced hillside and extends up to the top of the hill. The site is linear in form and approximately $30 \mathrm{~m}$ wide on the west end but is wider as one moves to the northeast. The total linear distance of the site is roughly $80 \mathrm{~m}$ (Fig. 2).

The site is characterized by a thin lithic scatter, although Rabdotus land snail shell clusters, burned rocks, and freshwater mussel shell fragments were observed. These types of remains often indicate an occupational site; therefore, shovel testing was carried out in order to record the depth and extent of cultural deposits, particularly in the area of the proposed sewer line. The results of these tests showed no subsurface deposits within the sewer 1 ine impact area. However, surface cultural material was observed on the top of the hill, $60 \mathrm{~m}$ northeast of the proposed sewer line.

The vegetation consisted of thin grasses, huisache, mesquite, and a number of large yucca cacti. The area is actively grazed by livestock. The soil is a brown to tan sandy loam (Venus-Frio-Trinity soil association), and no major soil changes were observed in the site area.

The proposed sewer line will parallel the already existing line. Since shovel testing revealed no subsurface deposits, no further archaeological work in conjunction with this site is recommended. 
This page has been

redacted because it

contains restricted

information. 
Site 41 BX 598 (Package C)

A prehistoric site, $41 \mathrm{BX} 598$ is located $30 \mathrm{~m}$ west of Leon Creek and $30 \mathrm{~m}$ south of the proposed pipeline. The site is situated where the flatter upland begins to slope down towards the creek. The site is oval in shape and is no more than $8 \mathrm{~m} \times 10 \mathrm{~m}$ (Fig. 3). This site is deflated and occurs within the flood zone of Leon Creek.

A thin lithic scatter characterizes this site with no diagnostic artifacts or cores observed. A large biface was noted; in addition, stream-rolled bifaces were also noted closer to Leon Creek. This site may have been a chipping station as no cultural remains other than chert flakes were observed.

The vegetation was quite thick along the creek and the slopes which led to the cleared flat land. The cleared area is the result of agricultural development. In the cleared area sunflowers and thick grasses occur. Large trees, including oak and mesquite, are found in abundance along Leon Creek.

This site shows no indication of being an intensive occupation and was found well outside of the impact zone and easement of the proposed sewer pipeline. No diagnostic artifacts were observed. Erosional areas were inspected, and there appears to be little subsurface depth, although no shovel tests were done. No further archaeological work in conjunction with this site is recommended.

Site 41 BX 599 (Package C)

Site 41 BX 599, a prehistoric site, is located along the southeast side of Leon Creek, $320 \mathrm{~m}$ south of the intersection of the earlier sewer line along Leon creek. The site is situated in the middle of an area which has been used as a gravel borrow pit and is flanked by additional gravel pits and on one end by a sand pit (Fig. 4).

The vegetation, for the most part, has been cleared, but a few mesquite trees are still standing. The soil consists of a gray sandy loam approximately $30 \mathrm{~cm}$ in depth on top of gravel. The exposed face of the gravel pit provided a view of the natural stratigraphy.

The artifacts observed include a Clear Fork tool, thin biface fragments, cores, flakes, and burned rock. These artifacts indicate that the site may have been occupational in nature. However, because of borrow pit activities, the artifacts found were not in original context. The site is very much disturbed.

The proposed sewer 1 ine wi11 pass $40 \mathrm{~m}$ to the southwest of $41 \mathrm{BX} 599$, therefore, the impact to the site would be negative. No further work is recommended at this time.

\section{BX 594 (Package J)}

Site 41 BX 594, a historic site, consists of the remains of a rectangular stone house about three by four meters in dimension. The house is situated approximately $400 \mathrm{~m}$ north of Gembler Road and on the west side of Salado Creek (Fig. 5). 
This page has been

redacted because it

contains restricted

information. 
This page has been

redacted because it

contains restricted

information. 
This page has been

redacted because it

contains restricted

information. 
The potential historic significance of this house is suggested by the cut limestone construction and a possible slate roof.

Three walls of the house, two of which are now fallen, were constructed of cut limestone blocks. The outer and inner wall surfaces had at one time been plastered smooth; plaster is evident on the one remaining standing wall. A fourth wa11, also fallen, was constructed of wood and was apparently the entrance as indicated by a doorway frame. In addition, a stone fireplace was observed in association with the single standing wall.

The ground surface surrounding the house has been cleared by a bulldozer, revealing artifacts that include unidentified ceramic fragments, abundant smal1 pieces of slate that may have been from the roof, and metal refuse.

Although the construction of the house, or at least the stones used in the construction, may be late 19 th or early 20 th century, associated electrical insulators indicate use during the 1930s. Without further study, the actual date of construction cannot be determined.

A preliminary research investigation has revealed that by 1946 , the house, although still standing at that time, had been abandoned. A 1946 plat of the land tract also indicates a barn and well nearby, both of which are now gone. An artesian spring nearby, however, may indicate the position of the well. The initial research reveals that in 1946 the land on which the house stands was owned by V. E. Berry and was originally in the G. Nunez Survey No. 151, County B 7ock 5096 .

Since the remains of this structure lie well away from the currently proposed pipeline route, it should not be affected. However, should the pipeline route change to the extent of impacting the house or property in any way, further archaeological and historical evaluation would be recommended.

\section{The Anthony Granieri Collection (Package B)}

This private collection of artifacts was recovered by Anthony Granieri, a landowner, while plowing fields on his property over an extended period of time. These fields are situated approximately two kilometers downstream from the Rigsby Road and Salado Creek intersection, on the west side of the creek. The collection had been made largely in a field between the pipeline easement and the creek.

The artifacts collected over the years by Mr. Granieri, all from his property, are related largely to the Late Prehistoric period (ca. A.D. 1000-1600) as indicated by Perdiz and Scallorn type arrow points.

\section{Testing at $41 \mathrm{BX} 333$ (Package D)}

The prehistoric site $41 \mathrm{BX} 333$ is situated at the confluence of Comanche and Leon Creeks. In March 1978, a team of archaeologists from the CAR-UTSA located and recorded site $41 \mathrm{BX} 333$. This site was initially described as "an intensive 
lithic scatter." However, no diagnostics were recorded, al though one medial biface fragment was recovered. The site was recorded as being densely overgrown with brush and altered by modern activities associated with the Leon Creek Treatment Plant Facility (Fox, McGraw, and Valdez 1978:28). At that time site 41 BX 333 was recommended for further study in the form of limited subsurface testing to determine the spatial and temporal extent (ibid.).

A Lewisville-Houston Black soil association is prevalent within the site area. Erosional features border the east and south sides of the indicated area (Fox, McGraw, and Valdez 1978).

At the time this site was first recorded, surface observation of a lithic scatter that occurred on the top and face of the bluff was reported (ibid.). In the current investigation, most of the site seemed to appear on the face of the bluff out of original context. Erosional activity apparently had dispersed lithic debris down the face of the bluff. The ground surface on the top of the bluff revealed a very light lithic scatter. This area has recently been disturbed by 7 andfill dumping and bulldozer land modification activities related to the water treatment plant development.

Testing was performed in a series of five $50-\mathrm{cm}^{2}$ shovel tests. These tests were excavated to depths ranging from 32 to $40 \mathrm{~cm}$ below the ground surface (Fig. 6). The excavated soils were screened through 1/4-inch wire mesh.

Two shove1 tests, ST1 and ST2 (Fig. 6) produced a smal1 amount of lithic debris from just below the surface. Shovel Test 1 produced two flakes, and Shovel Test 2 produced a total of three flakes; no other tests provided cultural materials.

Although the original plan was to excavate $1-m^{2}$ test units as needed, the series of shovel tests did not produce any subsurface evidence of cultural resources to indicate the necessity to do so. Discussion with persons who did the original survey indicates that local construction and erosion in the interim period have altered the area of $41 \mathrm{BX} 333$ to a notable degree, and now the site no longer appears to be a potentially significant cultural resource. Therefore, we recommend that no further work is needed.

\section{SUMMARY AND CONCLUSIONS}

A survey was made of five sewer pipeline routes (Packages $B, C, D$, and J) for the San Antonio 201 Wastewater Facilities Improvements Project. No significant cultural resources were found within or close to the pipeline easements. However, during the surveys, four prehistoric archaeological sites (41 BX 595, $41 \mathrm{BX} 596,41 \mathrm{BX} 598$, and $41 \mathrm{BX} 599$ ), and one possible historic site (41 BX 594), were noted in the vicinity of the pipeline easements, but well outside of the impact zones. Although these sites were found to be outside of the impact areas, they were briefly examined to determine their extent, potential significance, and physical relationships to the easements. None was found to extend into the 
This page has been

redacted because it

contains restricted

information. 
immediate area of the easements. A possibly significant site, 41 BX 594, may be of historical interest. None of the four prehistoric archaeological sites found are considered significant cultural resources and, therefore, none of these recorded sites were considered eligible for nomination to the National Register of Historic Places, or as a State Archeological Landmark. However, should the pipeline route near 41 BX 594 be altered to the extent of impacting the possible historical property, further historic research and field documentation would be recommended.

Testing was conducted at 41 BX 333 located at the Leon Creek Wastewater Treatment Plant facility. As a result of the field work, we have determined that this previously reported archaeological site is not a significant cultural resource and, therefore, not eligible for nomination to the National Register of Historic Places, or as a State Archeological Landmark. No further work is recommended at $41 \mathrm{BX} 333$.

In summary, the pipeline routes as currently proposed would not affect any known cultural resource, and no further studies are recommended in conjunction with this project. However, should cultural resources be uncovered during sewer line installations, the Texas Historical Commission should be notified.

\section{REFERENCES CITED}

Black, S. L. and A. J. McGraw

1984 The Panther Springs Creek Site: Cultural Change and Continuity Within the Upper Salado Creek Watershed, South-Central, Texas. Center for Archaeological Research. The University of Texas at San Antonio, Archaeological Survey Report 100 (in preparation).

Blair, W. F.

1950 The Biotic Provinces of Texas. Texas Journal of Science 1(2): 93-176.

Davis, W. B.

1974 The Mammals of Texas. Texas Parks and Wildlife Department, Bulletin 47.

Fawcett, W. B., Jr.

1972 The Prehistory of Bexar County: A Study of Previous Work in South Central Texas. Bulletin, Lower Plains Archaeological Society 2 (for 1971):23-44.

Fox, A. A.

1977 An Archaeological Assessment of the San Antonio 201 Wastewater Treatment Project. Center for Archaeological Research. The university of Texas at San Antonio, Archaeological Survey Report 41. 
Fox, A. A., A. J. McGraw, and F. Valdez, Jr.

1978 Archaeological Survey and Testing of Pipelines and Confluence Site, San Antonio 201 Wastewater Treatment Project. Center for Archaeological Research. The University of Texas at San Antonio, Archaeological Survey Report 66.

Gerstle, A., T. C. Kelly, and C. Assad

1978 The Fort Sam Houston Project: An Archaeological and Historical Assessment. Center for Archaeological Research. The University of Texas at San Antonio, Archaeological Survey Report 40.

Hester, T. R.

1980 Digging Into South Texas Prehistory. Corona Publishing Co., San Antonio.

Hester, T. R., F. A. Bass, Jr., A. A. Fox, T. C. Kelly, M. F. Chadderdon, and E. S. Harris

1974 Archaeological Survey of Areas Proposed for Modification in the Salado Creek Watershed, Bexar County, Texas. Center for Archaeological Research. The University of Texas at San Antonio, Archaeological Survey Report 3.

Hudson, W. R., Jr., W. M. Lynn, and D. Scurlock

1974 Walker Ranch, An Archeological Reconnaissance and Excavations in Northern Bexar County, Texas. Texas Historical Commission, Office of the State Archeologist, Report 26.

McGraw, A. J. and F. Valdez, Jr.

1977 A Preliminary Assessment of Archaeological Resources at Tobins Oakwe11 Farm, San Antonio, Texas. Center for Archaeological Research. The University of Texas at San Antonio, Archaeological Survey Report 43.

1978 Investigations of Prehistoric Rockshelter and Terrace Sites Along Portions of the Salado Creek Drainage, Northern Bexar County, Texas. Center for Archaeological Research, The university of Texas at San Antonio, Archaeological Survey Report 55.

Scurlock, D. and W. R. Hudson, Jr.

1973 An Archeological Investigation of Walker Ranch. Texas Historical Commission. Austin. 
18

Smith, H. P., Jr. and K. McDonald

1975 An Archaeological Survey of Friedrich Park, Bexar County, Texas. Center for Archaeological Research, The University of Texas at San Antonio, Archaeological Survey Report 12.

Taylor, F. B., R. B. Haley, and B. L. Richmond

1966 Soil Survey of Bexar County, Texas. U.S. Department of Agriculture, Soil Conservation Service, Series 1962:12.

Woolford, S. W.

1935 Types of Archeological Sites in Bexar County, Texas. Witt Memorial Museum, Archeological Bulletin 4. 
. 
